\title{
Bergenin, Suatu Dihidroisokumarin dari Kayu dan Kulit Batang Shorea Stenoptera Burck ${ }^{\S}$
}

\author{
Euis Holisotan Hakim $*^{\dagger}$, Rudiyansyah ${ }^{\dagger}$, Iqbal Musthapa ${ }^{\dagger} \&$ Koichi Takeya ${ }^{\ddagger}$ \\ $\dagger$ Kelompok Penelitian Kimia Organik Bahan Alam, Departemen Kimia, \\ Fakultas Matematika dan Ilmu Pengetahuan Alam, Institut Teknologi Bandung, \\ Jalan Ganeca 10, Bandung 40132 \\ $\$$ Tokyo University of Pharmacy \& Life Science, \\ Harinouchi 1432-1, Hachioji, Tokyo 192-0392, Japan
}

Sari. Bergenin, suatu dihidroisokumarin turunan asam glukopiranosilgalat, telah ditemukan untuk pertama kalinya pada ekstrak etil asetat kayu dan kulit batang, bersama-sama dengan (-)- $\alpha$-viniferin pada ekstrak diklorometana kulit batang, tumbuhan Shorea stenoptera. Struktur molekul bergenin telah ditetapkan berdasarkan analisis data spektroskopi UV, IR, MS, ${ }^{1} \mathrm{H}$ dan ${ }^{13} \mathrm{C}$ NMR. Senyawa bergenin memperlihatkan sitotoksisitas yang lemah terhadap sel murine leukemia P-388 ( $\left.\mathrm{IC}_{50}>100 \mu \mathrm{g} / \mathrm{mL}\right)$, dan toksisitas yang lemah pula terhadap benur udang Artemia salina $\left(\mathrm{LC}_{50}>500 \mu \mathrm{g} / \mathrm{mL}\right)$.

Kata kunci: Artemia salina; Bergenin; Murine leukemia P-388; Shorea stenoptera; (-)- $\alpha$-Viniferin.

Bergenin: a dihydroisocoumarin derivative from the heartwood and tree barks of Shorea stenoptera

\begin{abstract}
Bergenin, a dihydroisocoumarin derivative of glucopyranosyl gallic acid had been isolated for the first time from ethyl acetate extracts of the heartwood and tree bark, together with (-)- $\alpha$-viniferin from the tree bark of Shorea stenoptera. The structure of bergenin was elucidated based on analysis of spectroscopic data UV, IR, MS, ${ }^{1} \mathrm{H}$ and ${ }^{13} \mathrm{C}$ NMR. Bergenin showed weak cytotoxic activity against murine leukemia P-388 cells $\left(\mathrm{IC}_{50}>100 \mu \mathrm{g} / \mathrm{mL}\right)$, and also weak toxicity against Artemia salina shrimps $\left(\mathrm{LC}_{50}>500 \mu \mathrm{g} / \mathrm{mL}\right)$.
\end{abstract}

Keywords: Artemia salina; Bergenin; Murine leukemia P-388; Shorea stenoptera; (-)- $\alpha$-Viniferin.

$\S$ Bagian ke-6 dari seri "Ilmu Kimia Tumbuhan Dipterocarpaceae Indonesia". Untuk Bagian ke-5 lihat pustaka (8).

* Alamat untuk korespondensi: Tel. 022 - 250 2103; Fax. 022 - 250 4154;

E-mail: sjamsul@indo.net.id 


\section{$1 \quad$ Pendahuluan}

Dipterocarpaceae adalah suatu famili tumbuhan yang relatif besar dan terdistribusi di daerah tropika Asia, Afrika, dan Amerika. ${ }^{1}$ Kelompok tumbuhan ini memiliki sekitar 16 genus dan 600 spesies, termasuk empat genus utama, yakni Shorea, Hopea, Dipterocarpus, dan Vatica. ${ }^{2}$ Hutan tropika Indonesia sedikitnya memiliki sembilan genus Dipterocarpaceae. Shorea misalnya, yang merupakan genus terbesar dari Diperocarpaceae dan terdiri dari sekitar 150 spesies, bersama-sama dengan Dipterocarpus yang terdiri dari 70 spesies, hanya terdapat di wilayah Malesia, sebagian besar di antaranya tersebar di seluruh Indonesia, mulai dari Sumatera, Jawa, Kalimantan, hingga Maluku. Di Indonesia, kelompok tumbuhan Dipterocarpaceae, yang dikenal dengan nama meranti, keruwing, damar, dan tengkawang, mempunyai nilai ekonomi yang tinggi, dan merupakan komoditi ekspor yang penting berupa kayu bangunan atau plywood. ${ }^{3}$

Telah dilaporkan pula bahwa Dipterocarpaceae adalah sumber senyawasenyawa kimia polifenol yang memperlihatkan berbagai bioaktivitas, seperti kemoprefentif untuk kanker, sitotoksisitas terhadap sel tumor manusia, hepatoprotektif, antiinflamasi, menghambat penyebaran histamin STP-ase lambung dan topoisomerase II, antibakterial, antifungal, dan anti-HIV. ${ }^{4-12}$<smiles></smiles>

1

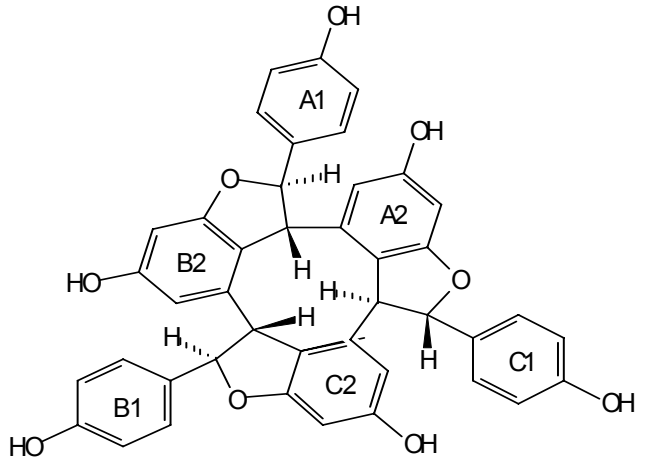

2

Dalam rangka program penelitian kami untuk mengungkapkan dan menemukan senyawa-senyawa kimia yang berguna dari tumbuh-tumbuhan tropika Indonesia, maka penelitian terhadap tumbuhan Shorea stenoptera Burck., yang berasal dari Kalimantan Barat dan dikenal dengan nama daerah Tengkawang Tungkul, telah kami lakukan dan merupakan penelitian kimia pertama untuk spesies ini. Pada kesempatan ini akan dilaporkan mengenai penemuan 
senyawa bergenin (1), suatu senyawa dihidroisokumarin turunan asam glukopiranosilgalat dari ekstrak etil asetat kayu dan kulit batang, bersama-sama dengan (-)- $\alpha$-viniferin, suatu trimer oligoresveratrol (2), dari ekstrak diklorometana kulit batang tumbuhan S. stenoptera. Senyawa $\mathbf{2}$ telah ditemukan pula sebelumnya pada $S$. guiso. ${ }^{13}$ Struktur senyawa 1 telah ditetapkan berdasarkan analisis spektrum UV, IR, MS, dan NMR, termasuk 1D dan 2D NMR, seperti ${ }^{1} \mathrm{H}^{1}{ }^{\mathrm{H}} \mathrm{COSY}, \mathrm{HMQC}, \mathrm{HMBC}$, dan NOESY.

\section{Percobaan}

Umum. Pada percobaan ini data fisik titik leleh ditentukan dengan menggunakan alat penetapan titik leleh mikro. Spektrum UV dan IR diukur masing-masing dengan spektrofotometer Varian Cary 100 Conc. dan ONE Perkin Elmer. Spektrum ${ }^{1} \mathrm{H}$ dan ${ }^{13} \mathrm{C}$ NMR diukur menggunakan spektrometer JEOL JNM A6000 yang bekerja pada $600,2 \mathrm{MHz}\left({ }^{1} \mathrm{H}\right)$ dan $150,9 \mathrm{MHz}\left({ }^{13} \mathrm{C}\right)$ menggunakan TMS sebagai standar internal. Spektrum massa tumbukan elektron (EIMS) diperoleh menggunakan spektrometer massa JEOL JMSAM20. Kromatografi cair vakum (KCV) dilakukan menggunakan Si gel Merck $60 \mathrm{GF}_{254}$, kromatografi tekan dengan Si gel Merck 60 (230 - 400 mesh), analisis kromatografi lapis tipis (KLT) pada pelat aluminium berlapis Si gel Merck Kieselgel $60 \mathrm{~F}_{254}, 0,25 \mathrm{~mm}$, dan uji aktivitas dilakukan menggunakan sel murine leukemia P-388 dan benur udang Artemia salina Leach.

Pengumpulan bahan tumbuhan. Bahan tumbuhan berupa kayu batang dan kulit batang S. stenoptera dikumpulkan pada bulan Juli 2000 dari hutan Engkuli, dusun Liku, desa Beringin, Kabupaten Sanggau, Kalimantan Barat. Spesies ini diidentifikasi oleh Herbarium Bogoriense, Pusat Penelitian dan Pengembangan Biologi, Lembaga Ilmu Pengetahuan Indonesia, Bogor, dan spesimennya tersimpan di herbarium tersebut.

Ekstraksi dan isolasi. Kayu batang yang telah dikeringkan dan digiling $(3,8$ $\mathrm{kg}$ ) dimaserasi dengan metanol $(8 \mathrm{l})$. Setelah pelarut diuapkan pada tekanan rendah, diperoleh ekstrak metanol berupa residu berwarna coklat (165 g). Ekstrak metanol dilarutkan kembali dalam metanol encer (40\%) kemudian dipartisi berturut-turut dengan heksana, diklorometana, dan etil asetat. Dari ekstrak etil asetat, setelah pelarut diuapkan pada tekanan rendah, diperoleh ekstrak berupa padatan berwarna coklat $(13,2 \mathrm{~g})$. Ekstrak etil asetat ini $(13,2 \mathrm{~g})$ difraksinasi dengan teknik kromatografi $\mathrm{KCV}$ menggunakan berturut-turut eluen heksana, campuran heksana-etil asetat, etil asetat-metanol, dan metanol dengan kepolaran yang terus ditingkatkan. Fraksi-fraksi yang diperoleh digabungkan berdasarkan analisis KLT, menghasilkan delapan fraksi utama (E1-E8). Fraksi utama keenam (8,0 g) difraksinasi lebih lanjut dengan teknik $\mathrm{KCV}$ menggunakan eluen diklorometana, campuran diklorometana-metanol, 
dan metanol dengan kepolaran yang terus ditingkatkan, menghasilkan sepuluh fraksi gabungan (A1-A10). Fraksi gabungan keenam $(4,1 \mathrm{~g})$ difraksinasi lebih lanjut menggunakan sistem eluen heksana, campuran heksana-etil asetat, etil asetat-metanol, aseton, dan metanol, dengan kepolaran yang terus ditingkatkan, menghasilkan enam fraksi (B1-B6). Dari fraksi kedua (536 mg) diperoleh kristal berwarna coklat muda yang dikristalisasi dari campuran pelarut etil asetat-metanol menghasilkan bergenin (1) $(82,4 \mathrm{mg})$ berupa kristal tak berwarna, t.1. $246-247{ }^{\circ} \mathrm{C}$, yang homogen pada KLT menggunakan tiga sistem eluen yang berbeda. Dengan cara yang sama, dari fraksi etil asetat kulit batang $(12,0 \mathrm{~g})$ diperoleh pula bergenin (1) (242 mg), sedangkan dari fraksi diklorometana $(14,0 \mathrm{~g})$ diperoleh (-)- $\alpha$-viniferin (2) (12 mg) berupa kristal berwarna kuning, t.l. $232{ }^{\circ} \mathrm{C}$, yang dikristalisasi dari campuran pelarut kloroform-heksana.

Bergenin (1) diperoleh sebagai kristal tak berwarna, t.1. 246-247 ${ }^{\circ} \mathrm{C} ;[\alpha]^{26}{ }_{\mathrm{D}}-$ $23^{\circ}$ (c 1,0, MeOH), IR (KBr) $v_{\text {maks }} 3420(\mathrm{OH}), 1703(\mathrm{C}=\mathrm{O}), 1614,1528,1464$ $\mathrm{cm}^{-1}$ (aromatik); UV (MeOH) $\lambda_{\text {maks }} 219,273,320$ (bahu) nm; $(\mathrm{MeOH}+\mathrm{NaOH})$ 206, 241, 290, 342 (bahu) nm; ${ }^{1} \mathrm{H}-\mathrm{NMR}\left(\mathrm{CD}_{3} \mathrm{OD}, 600,0 \mathrm{MHz}\right): \delta 7.09(1 \mathrm{H}, \mathrm{s}$, $\mathrm{H}-3), 4,96(1 \mathrm{H}, \mathrm{d}, J=10,4 \mathrm{~Hz}, \mathrm{H}-8), 4,06(1 \mathrm{H}, \mathrm{dd}, J=9,5$ dan $10,4 \mathrm{~Hz}, \mathrm{H}-9)$, $4,03(1 \mathrm{H}, \mathrm{dd}, J=1,9$ dan $11,8 \mathrm{~Hz}, \mathrm{H}-13 \mathrm{eq}), 3,90\left(3 \mathrm{H}, \mathrm{s}, \mathrm{OCH}_{3}\right), 3,81(1 \mathrm{H}, \mathrm{dd}, J$ $=8,7$ dan $9,5 \mathrm{~Hz}, \mathrm{H}-10), 3,69(1 \mathrm{H}, \mathrm{dd}, J=6,9$ dan $11,8 \mathrm{~Hz}, \mathrm{H}-13 \mathrm{ax}), 3,66(1 \mathrm{H}$, ddd, $J=1,9 ; 6,9$ dan $8,7 \mathrm{~Hz}, \mathrm{H}-12), 3,43(1 \mathrm{H}, \mathrm{dd}, J=8,7$ dan $9,5 \mathrm{~Hz}, \mathrm{H}-11)$. ${ }^{13} \mathrm{C}-\mathrm{NMR}\left(\mathrm{CD}_{3} \mathrm{OD}, 150,9 \mathrm{MHz}\right): \delta 165,7$ (C-1), 152,4 (C-4), 149,5 (C-6), 142,3 (C-5), 119,4 (C-2), 117,3 (C-7), 111,1 (C-3), 83,1 (C-12), 81,4 (C-9), 75,6 (C10), 74,3 (C-8), 71,9 (C-11), 62,7 (C-13), 60,9 $\left(\mathrm{OCH}_{3}\right)$. FABMS m/z [M+1] 329 (24), 209 (12), 152 (36), 135 (60), 119 (76), 85 (100).

Uji biologi. Pada pengujian sitotoksisitas menggunakan sel murine leukemia P388 yang dibiakkan sesuai dengan protokol seperti telah diuraikan sebelumnya, ${ }^{14}$ senyawa 1 memperlihatkan $\mathrm{IC}_{50}>100 \mu \mathrm{g} / \mathrm{mL}$, sedangkan uji toksisitas menggunakan benur udang Artemia salina, mengikuti cara yang diuraikan oleh Meyer dkk., ${ }^{15}$ senyawa 1 memperlihatkan $\mathrm{LC}_{50}>500 \mu \mathrm{g} / \mathrm{mL}$.

\section{Pembahasan}

Pada ekstraksi kayu dan kulit batang S. stenoptera dengan metanol, kemudian partisi ekstrak metanol dengan etil asetat telah ditemukan suatu senyawa dihidroisokumarin turunan asam glukopiranosilgalat, yaitu bergenin (1), sedangkan pada partisi ekstrak metanol kulit batang dengan diklorometan ditemukan senyawa polifenol turunan trimer resveratrol, yakni (-)- $\alpha$-viniferin (2), yang telah ditemukan sebelumnya dari tumbuhan $S$. guiso. ${ }^{13}$ Senyawasenyawa ini diperoleh melalui beberapa tahap fraksinasi, diikuti oleh pemilihan 
fraksi berdasarkan analisis kromatografi lapis tipis (KLT), dan pemisahan kromatografi.

Senyawa bergenin (1) diperoleh sebagai kristal tak berwarna, t.l. $246-247{ }^{\circ} \mathrm{C}$. Spektrum IR (KBr) senyawa 1 memperlihatkan adanya gugus hidroksi 3420 $\left(\mathrm{cm}^{-1}\right)$, gugus $\mathrm{C}=\mathrm{O} \delta$-lakton $\left(1703 \mathrm{~cm}^{-1}\right), \mathrm{C}=\mathrm{C}$ dan struktur aromatik (1614, $\left.1528,1464 \mathrm{~cm}^{-1}\right)$, sedangkan spektrum UV $(\mathrm{MeOH})$ memperlihatklan serapan untuk sistem benzoil pada $\lambda$ maks $(\log \varepsilon) 219,273,320 \mathrm{~nm}^{16}$ Spektrum IR dan UV ini merupakan ciri khas untuk asam elagat. ${ }^{17}$ FABMS menunjukkan ion $[\mathrm{M}+1]^{+}$pada $m / z 329$ yang selaras dengan rumus molekul $\mathrm{C}_{14} \mathrm{H}_{16} \mathrm{O}_{9}$.

Sinyal-sinyal ${ }^{1} \mathrm{H}$ dan ${ }^{13} \mathrm{C}$ NMR senyawa 1 dapat dijelaskan secara rinci dengan bantuan spektrum NMR dua dimensi (2D), seperti spektrum korelasi homonuklir $\left({ }^{1} \mathrm{H}-{ }^{1} \mathrm{H}\right.$ COSY), spektrum korelasi heteronuklir ${ }^{1} \mathrm{H}^{13} \mathrm{C}$ COSY kuantum rangkap (HMQC), dan spektrum korelasi heteronuklir jarak jauh (HMBC). Spektrum ${ }^{1} \mathrm{H}$ NMR senyawa $\mathbf{1}$ memperlihatkan adanya satu set sinyal untuk enam proton oksikarbon alifatik pada $\delta 3,43(1 \mathrm{H}$, dd, $J=8,7$ dan $9,5 \mathrm{~Hz}$, $\mathrm{H}-11)$. 3,66 (1H, ddd, $J=1,9 ; 6,9$ dan 8,7 Hz, H-12), 3,69 (1H, dd, $J=6,9$ dan $11,8 \mathrm{~Hz}, \mathrm{H}-13 \mathrm{ax}), 3,81(1 \mathrm{H}, \mathrm{dd}, J=8,7$ dan $9,5 \mathrm{~Hz}, \mathrm{H}-10), 4,03(1 \mathrm{H}, \mathrm{dd}, J=1,9$ dan $11,8 \mathrm{~Hz}, \mathrm{H}-13 \mathrm{eq}), 4,06(1 \mathrm{H}, \mathrm{dd}, J=9,5$ dan $10,4 \mathrm{~Hz}, \mathrm{H}-9)$, dan 4,96 (1H, d, $J=10,4 \mathrm{~Hz}, \mathrm{H}-8)$, yang merupakan ciri khas suatu sistem glukopiranosil. Spektrum ${ }^{1} \mathrm{H}$ NMR senyawa $\mathbf{1}$ juga menunjukkan adanya satu singlet untuk satu proton aromatik pada $\delta 7.09(1 \mathrm{H}, \mathrm{s}, \mathrm{H}-3)$ dan satu singlet untuk satu gugus metoksi pada $\delta 3,90\left(3 \mathrm{H}, \mathrm{s}, \mathrm{OCH}_{3}\right)$, untuk sistem aromatik yang tersubstitusi pada posisi-1,3,4,5,6 di mana proton aromatik tersebut terikat pada posisi 2 . Berdasarkan data ${ }^{1} \mathrm{H}$ NMR seperti dikemukakan di atas (Gambar 1) dapat disimpulkan bahwa senyawa 1 adalah bergenin. Kesimpulan ini didukung oleh spektrum ${ }^{13} \mathrm{C}$ NMR, DEPT, dan HMQC senyawa 1 yang menunjukkan adanya resonansi yang terpisah untuk 14 atom karbon, termasuk di antaranya satu gugus metoksi, satu gugus oksimetilen, lima gugus oksimetin alifatik, satu gugus metin aromatik, tiga gugus oksiaril, tiga atom karbon kuaterner termasuk satu gugus karbonil, yang sesuai untuk struktur bergenin (1) (Gambar 2).

Bukti selanjutnya mengenai pola substitusi pada struktur senyawa 1 diperoleh dari pengukuran-pengukuran HMBC (Gambar 3). Spektrum korelasi jarak jauh ${ }^{1} \mathrm{H}-{ }^{13} \mathrm{C}(\mathrm{HMBC})$ memperlihatkan korelasi-korelasi antara proton pada $\mathrm{C}-3(\delta$ $7,08)$ dengan lima atom karbon kuaterner pada C-1 $(\delta 165,7), \mathrm{C}-2(\delta 119,4), \mathrm{C}-$ $4(\delta 152,4), \mathrm{C}-5(142,3)$, dan C-7 (117,3), sedangkan proton gugus metoksi menunjukkan korelasi jarak jauh dengan atom karbon oksiaril pada $\mathrm{C}-5$ ( $\delta$ 142,3). Begitu pula, spektrum HMBC memperlihatkan korelasi jarak jauh antara proton pada C-8 $(\delta 4,96)$ dengan tiga atom karbon kuaterner pada $\mathrm{C}-2(\delta$ 119.4), C-6 ( $\delta 149,5)$, dan C-7 ( $\delta 117,3)$. Selanjutnya, terdapat pula korelasi 
jarak jauh antara proton pada C-8 $(\delta$ 4,96) dan C-9 $(\delta$ 4,06) masing-masing dengan atom karbon oksimetin pada C-10 $(\delta 75,6)$, dan atom karbon kuaterner pada C-7 $(\delta 117,3)$. Spektrum HMBC juga menunjukkan adanya korelasi jarak jauh antara proton pada $\mathrm{C}-9(\delta$ 4.06) dan $\mathrm{C}-10(\delta 3,81)$ dengan atom karbon oksimetin pada C-8 $(\delta 74,3)$ dan C-11 $(\delta 71,9)$, sedangkan proton pada $\mathrm{C}-11(\delta$ $3,43)$ menunjukkan korelasi jarak jauh dengan atom karbon oksimetin pada $\mathrm{C}$ $10(\delta$ 75.6), C-12 ( $\delta 83,1)$, dan atom karbon oksimetilen C-13 $(\delta 62,7)$. Begitu pula, spektrum HMBC memperlihatkan korelasi jarak jauh antara proton pada C-12 ( $\delta 3,69)$ dengan karbon oksimetin pada C-8 $(\delta 74,3)$ dan C-11 $(\delta 71,9)$, sedangkan proton metilen pada C-13ax $(\delta 3,69)$ menunjukkan korelasi jarak jauh dengan karbon pada $\mathrm{C}-12(\delta 83.1)$. Selanjutnya, konfigurasi relatif sebagai C-8 $\alpha, 9 \beta$ dapat ditunjukkan oleh percobaan-percobaan NOESY (Gambar 4) dan didukung oleh harga-harga geseran kimia dan konstanta kopling ${ }^{1} \mathrm{H}$ NMR dari H-8 dan H-9. Adapun, pola kopling H-8 $\left(\delta 4,96, \mathrm{~d}, J_{8,9}=10,4 \mathrm{~Hz}\right)$ dan H-9 (d 4,06 , dd, $J_{8,9}=10,4$ dan $J_{9,10}=9,5 \mathrm{~Hz}$ )

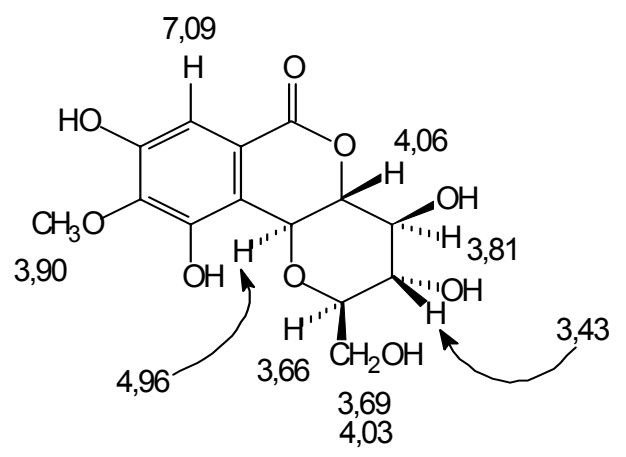

Gambar 1 Distribusi sinyal ${ }^{1} \mathrm{H}$ NMR pada senyawa 1.<smiles>COc1c(O)cc2c(c1O)C1O[C@H](CO)[C@@H](O)[C@H](O)C1OC2=O</smiles>

Gambar 2 Distribusi sinyal ${ }^{13} \mathrm{C}$ NMR pada senyawa $\mathbf{1 .}$ 
menunjukkan orientasi aksial dari H-8 dan H-9. Begitu pula, pola kopling H-10 $\left(\delta 3,81\right.$, dd, $J_{9,10}=9,5$ dan $\left.J_{10,11}=8,7 \mathrm{~Hz}\right)$ dan H-11 $\left(\delta 3,43\right.$, dd, $J_{10,11}=8,7$ dan $J_{11,12}=9,5 \mathrm{~Hz}$ ) menunjukkan bahwa $\mathrm{H}-10$ dan $\mathrm{H}-11$ kedua-duanya mempunyai orientasi aksial (Gambar 4). Percobaan-percobaan HMBC dan NOESY ini mendukung pula pola substitusi C-1,3,4,5,6 dan letak gugus arilmetoksil pada cincin aromatik, dan adanya substituen glukopiranosil pada posisi C-7.

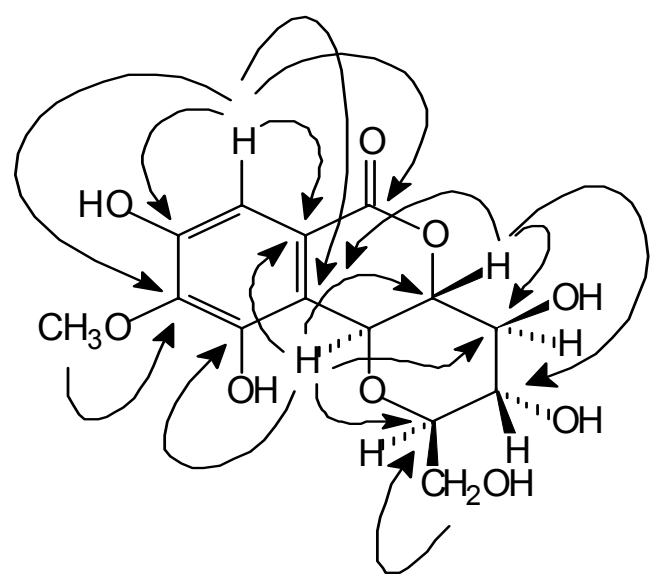

Gambar 3 Beberapa korelasi HMBC yang utama senyawa 1.

Bukti selanjutnya mengenai struktur senyawa 1 diperoleh dari pembandingan data ${ }^{1} \mathrm{H}$ dan ${ }^{13} \mathrm{C}$ NMR senyawa 1 yang sama dengan data yang telah dilaporkan sebelumnya untuk senyawa bergenin. ${ }^{18}$ Dengan demikian dapat disimpulkan bahwa senyawa 1 adalah bergenin, yang merupakan penemuan pertama dari $S$. stenoptera.

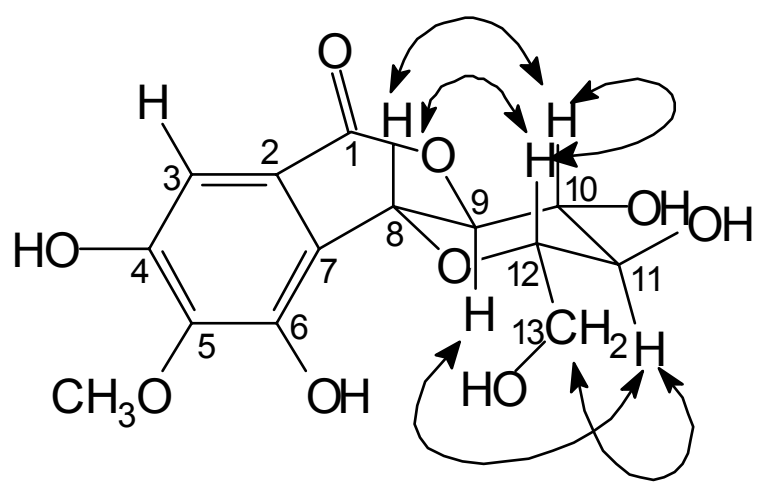

Gambar 4 Beberapa interaksi utama pada spektrum NOESY senyawa 1. 
Pembandingan sifat-sifat fisik dan spektroskopi senyawa (2) menunjukkan bahwa data ini identik dengan yang telah dilaporkan sebelumnya untuk stilbenoid trimer (-)- $\alpha$-viniferin. ${ }^{13}$ Identitas senyawa (2) ini dikonfirmasikan dengan cara ko-KLT menggunakan senyawa autentik.

Pada pengujian sitotoksisitas menggunakan sel murine leukemia P-388 yang dibiakkan sesuai dengan protokol seperti telah diuraikan sebelumnya, ${ }^{14}$ senyawa 1 memperlihatkan $\mathrm{IC}_{50}>100 \mu \mathrm{g} / \mathrm{mL}$, sedangkan uji toksisitas menggunakan benur udang Artemia salina, mengikuti cara yang diuraikan oleh Meyer dkk., ${ }^{15}$ senyawa 1 memperlihatkan $\mathrm{LC}_{50}>500 \mu \mathrm{g} / \mathrm{mL}$. Namun, telah dilaporkan sebelumnya bahwa senyawa 1 yang ditemukan pula antara lain pada $S$. robusta bersifat anti-HIV dan antihepatotoksik. ${ }^{19}$

Senyawa (1) adalah suatu dihidroisokumarin turunan asam glukopiranosilgalat yang unik,, yang juga pernah ditemukan pada $S$. robusta. Keberadaan senyawa ini, yang jarang ditemukan pada Dipteropcarpaceae, adalah sangat menarik, dan mungkin mempunyai makna kemotaksonomi. Adapun keberadaan senyawa (2), sebagai suatu senyawa oligomer resveratrol yang sering ditemukan dari spesies Dipterocarpaceae, dapat dianggap sebagai tanda kimiawi atau "chemical marker" dari famili Dipterocarpaceae. Penelitian kimia terhadap S. stenoptera masih kami lanjutkan.

\section{$4 \quad$ Kesimpulan}

Melanjutkan penelitian kami terhadap tumbuh-tumbuhan hutan tropika Indonesia yang mempunyai nilai ekonomi tinggi, khususnya tumbuh-tumbuhan yang termasuk famili Dipterocarpaceae, maka pada penelitian sekarang ini telah berhasil ditemukan untuk pertama kalinya senyawa bergenin (1), bersama-sama dengan senyawa (-)- $\alpha$-viniferin (2) dari spesies $S$. stenoptera. Senyawa 1 memperlihatkan toksisitas yang rendah baik terhadap sel murine leukemia P388 maupun benur udang Artemia salina.

\section{Ucapan Terima Kasih}

Terima kasih disampaikan kepada KPH Sanggau serta Kanwil Kehutanan dan Perkebunan Kalimantan Barat atas bantuannya dalam mengumpulkan bahan tumbuhan yang diperlukan untuk penelitian ini. Terima kasih disampaikan pula kepada Herbarium Bogoriense, Pusat Penelitian dan Pengembangan Biologi, LIPI, Bogor, yang telah membantu mengidentifikasi spesimen tumbuhan. 


\section{Daftar Pustaka}

1. Hegnauer, R., Chemotaxonomie der Pflantzen, Vol. 4, Birkhauser Verlag Basel und Stuttgart (1966).

2. Cronquist, A., An Intergrated System of Classification of Flowering Plants, Columbia University Press, New York (1981).

3. Soerianegara \& Lemmens, R. H. M. J (Eds.), Plant Resources of Southeast Asia, No. 5(1). Timber Trees: Major Commercial Timbers", PROSEA, Bogor, Indonesia (1994).

4. Hakim, E. H., Review: Oligostilbenoid dari Tumbuh-Tumbuhan Dipterocarpaceae, Bull. Soc. Nat. Prod. Chem. (Indonesia), 2(1), 1-19 (2002).

5. Muharini, R., Hakim, E. H., Achmad, S. A., Aimi, N., Makmur, L., Syah, Y. M., Juliawaty, L.D., Kitajima, M. \& Takayama, H., Davidiol A, A Stilbenoid Derivative from the Tree Bark of Shorea guiso Blume, Bull. Soc. Nat. Prod. Chem. (Indonesia), 2(2), 37-40 (2002).

6. Tukiran, Achmad, S. A., Hakim, E. H., Juliawaty, L. D., Sakai, K. \& Syah, Y. M., Oligostilbenoids from Shorea balangeran Burck (Dipterocarpaceae), Bull. Soc. Nat. Prod. Chem. (Indonesia), 3(1), 2431.

7. Winata, I. N. A., Syah, Y. M., Achmad, S. A., Hakim, E. H., Juliawaty, L. D., Aimi, N. \& Choudhary, M. I., Hemsleyanol D, Suatu Tetramer Stilbenoid dari Kulit Batang Shorea leprosula Miq., Bull. Soc. Nat. Prod. Chem. (Indonesia), 3(1), 37-40 (2002).

8. Aminah, N. S., Achmad, S. A., Aimi, N., Ghisalberti, E. L., Hakim, E. H., Kitajima, M., Syah, Y. M. \& Takayama, H., Diptoindonesin A, A New $C$-Glucoside of $\varepsilon$-Viniferin from Shorea seminis (Dipterocarpaceae), Fitoterapia, 73, 501-507 (2002).

9. Ito, T., Tanaka, T., Ido, Y., Nakaya, K., Iinuma, M. \& Riswan, S., Stilbenoids Isolated from Stem Bark of Shorea hemsleyana, Chem. Pharm. Bull., 48(7), 1001-1005 (2000).

10. Tanaka, T., Ito, T., Ido, Y., Son, T-K, Nakaya, K., Iinuma, M., Ohyama, M. \& Cheladurai, V., Stilbenoids in the Stem Bark of Hopea parviflora, Phytochemistry, 53, 1015-1019 (2000).

11. Tanaka, T., Ito, T., Nakaya, K., Iinuma, M., Takahashi, Y., Naganawa, H., Matsuura, N. \& Ubukata, Vaticanol D, a Novel Resveratrol Hexamer Isolated from Vatica rassak, Tetrahedron Lett., 41, 7929-7932 (2000).

12. Seo, E-K, Chai, H., Constant L., Santisuk, T., Reutrakul, V., Beecher, C. W. W., Farnsworth, N. R., Cordell, G. A., Pezzuto, J. M. \& Kinghorn, A. D., Resveratrol Tetramers from Vatica diospyroides, J. Org. Chem., 64, 6976-6983 (1999). 
13. Hakim, E. H., Muharini, R., Aimi, N., Kitajima, M. \& Takayama, H., (-)- $\alpha$-Viniferin dan Davidiol D, Dua Resveratrol Trimer dari Shorea guiso, submitted.

14. Suhartati, T., Achmad, S. A., Aimi, N., Hakim, E. H., Kitajima, M., Takayama, H. \& Takeya, K., Artoindonesianin L, A New Prenylated Flavone with Cytotoxic Activity from Artocarpus rotunda, Fitoterapia, 72, 912-918 (2001).

15. Meyer, N., Ferrigini, N. R., Putnam, J. E., Jacobsen, D. E., Nichols, D. E. \& McLaughlin, J. L., Brine Shrimp: A Convinient General Bioassay for Active Plant Constituents, Planta Med. 45, 31 (1982).

16. Taneyama, M., Yoshida, S., Kobayashi, M. \& Hasegawa, M., Isolation of norbergenin from Soxifraga stolonifera, Phytochemistry, 22(4), 10-53-54 (1983).

17. Gunawardana, Y. A. G. P., Gunawardana, P., Kumar, N. S. \& Sultanbawa, M. U. S., Chemical Investigation of Ceylonese Plants, Part. 35. Three Hydroxyellagic Acid Methyl Ethers, Chrysophanol, and Scopoletin from Shorea worthingtonii and Vativa obscura, Phytochemistry, 18(6), 1017-1019 (1979).

18. Scott, A. I., Interpretation of the Ultraviolet Spectra of Natural Products, Pergamon Press, London (1964).

19. Saraswathy, A., Sasikala, E. \& Purushothaman, K. K., Bergenin from Shorea robusta Gaertn, Indian Drugs, 26(10), 574-575 (1989). 